\title{
Pelatihan Pembuatan Pupuk Organik Cair dari Urin Kelinci pada Kelompok Peternak "Kelinci" di Desa Tanjungsari Kecamatan Panekan Kabupaten Magetan
}

\author{
Wuye Ria Andayanie \\ \# Program Studi Agroteknologi, Universitas Merdeka Madiun, Jalan Serayu no 79,Madiun, 63133 \\ E-mail:wuye.andayanie@gmail.com
}

\begin{abstract}
Raising rabbits is one of the main activities of the business group in Tanjungsari Village, Panekan District, Magetan Regency. Raising rabbits provides several advantages, including: 1) feed that is easy to obtain and cheap; 2) easy maintenance method; 3) the number of children produced from the parent is counted. In addition, rabbit urine can be used for liquid organic fertilizer. Rabbit urine as one of the mainstay organic fertilizers for farmer groups in Panekan District, so far the potential of rabbit urine has not been developed optimally. The objectives of this activity are to: (1) utilize waste derived from rabbit urine; (2) improve the management of rabbit breeder groups. The method used is education and facilitation. Education is carried out by: (1) providing counseling to groups of rabbit breeders for the manufacture of organic fertilizer derived from rabbit urine; (2) introduction of fertilizer-making equipment; (3) assistance for training on the use of tools, group motivation, marketing management of organic fertilizer products derived from rabbit urine. Facilitate by providing appropriate tools needed by the group for the manufacture of organic fertilizers. This effort is carried out to utilize waste derived from rabbit urine and increase economic added value for rabbit breeders.
\end{abstract}

Keywords—:organik counseling; socialization; rabbit urine; organic fertilizer

\section{PENDAHULUAN}

Penggunaan pupuk kimia yang telah berlangsung lama menyebabkan lahan pertanian di Indonesia telah mengalami penurunan kesuburan. Hal ini disadari oleh para petani, mengingat kesuburan tanah sangat berpengaruh terhadap hasil panen yang diperoleh. Dalam rangka mengembalikan kesuburan lahan, sejumlah peternak kelinci yang tergabung dalam kelompok peternak "kelinci" memanfaatkan air kencing kelinci untuk difermentasi dan diolah menjadi pupuk organik yang bermanfaat untuk tanaman. Produksi pupuk semacam ini selain ditujukan untuk memenuhi kebutuhan sendiri dan mengurangi biaya yang harus dikeluarkan dalam kegiatan usaha tani juga dijual untuk menambah pendapatan keluarga. Hal ini karena semakin sulit diperoleh karena harganya semakin mahal.

Dewasa ini pengelolaan pertanian dengan sistem organik memang masih terbatas, tetapi seiring dengan meningkatnya kesadaran petani, lambat laun penggunaan pupuk organik yang ramah lingkungan akan menjadi kebutuhan petani. Kelompok peternak kelinci yang ada di Kecamatan Panekan sudah lama dibentuk, namun tidak ada perkembangan dalam mengelola limbah urin kelinci. Kenyataannya sampai saat ini, keberadaan kelompok peternak kelinci tersebut belum dapat meningkatkan penghasilan anggotanya. Pemasaran urin kelinci selama ini hanya dibeli oleh pedagang pengumpul yang datang ke rumah-rumah peternak kelinci yang dibeli dengan harga yang relatif murah. Meskipun ketersediaan kelinci lebih banyak dibandingkan kotoran ternak lainnya di desa tersebut.

Limbah adalah sisa suatu usaha atau kegiatan, yang mengandung bahan berbahaya atau beracun yang karena sifat, konsentrasi, atau jumlahnya, baik secara langsung atau tidak langsung akan dapat membahayakan lingkungan, kesehatan, kelangsungan hidup manusia atau mahluk hidup lainnya (Mahida,1984). Setiap limbah perlu dikarakteristik terlebih dahulu sebelum rancangan proses dimulai. Sifat limbah cair yang perlu diketahui adalah volume aliran, konsentrasi organik, karakteristik dan toksisitas. Tingkat bahaya keracunan yang disebabkan oleh limbah juga bergantung pada jenis dan karakteristik limbah. Berdasarkan sumber atau asal limbah, maka limbah dapat dibagi beberapa golongan yaitu:

a. Limbah domestik, yaitu semua limbah yang berasal dari kamar mandi, dapur, tempat cucian pakaian dan sebagainya, yang secara kuantitatif limbah tersebut terdiri atas zat organik padat maupun cair, bahan berbahaya dan beracun (B-3), garam terlarut, lemak. 
Website : http://dayamas.unmermadiun.ac.id/index.php/dayamas

b. Limbah non domestik, yaitu limbah yang berasal dari pabrik, industri, pertanian, peternakan, dan trasportasi serta sumber-sumber lainnya. Limbah pertanian biasanya terdiri atas pestisida, bahan pupuk dan lainnya (Kristanto, 2002).

Mengingat adanya keterbatasan teknologi pada kelompok peternak kelinci untuk pengelolaan limbah cair dari urin kelinci mengakibatkan rendahnya produktivitas dan efisiensi produksi pupuk organik tersebut. Prinsip pembuatan pupuk organik cair yang berasal dari urin kelinci skala kecil adalah menampung limbah organik dari kelinci dan memproses sehingga bermanfaat sebagai pengganti pupuk kimia yang semakin mahal dan tidak ramah lingkungan. Teknologi pemanfaatan urin kelinci menjadi pupuk organik, walaupun sederhana namun mayoritas peternak kelinci belum mampu memanfaatkannya. Hal tersebut disebabkan minimnya pelatihan dan penyuluhan kepada masyarakat dan rendahnya kepedulian pemerintah daerah untuk serius mengoptimalkan sektor peternakan, khususnya kelinci.

Tujuan dari pelatihan ini adalah memperkenalkan teknologi pembuatan pupuk organik dari urin kelinci melalui pelatihan kepada kelompok peternak "Kelinci" di Desa Tanjungsari Kecamatan Panekan Kabupaten Magetan dengan memanfaatkan limbah urin kelinci. Pemanfaatan limbah urin kelinci menjadi pupuk organik cair secara tidak langsung juga dapat mengatasi pencemaran udara (bau tidak sedap), pencemaran tanah dan air dengan adanya leaching dan eutrofikasi yang menyebabkan terganggunya biota sungai, serta pencemaran biologis (penyakit) melalui vektor lalat. Diharapkan dengan pelatihan ini, selain dapat menyediakan pupuk organik juga dapat meningkatkan nilai ekonomis limbah yang berasal dari urin kelinci sebagai pupuk organik.

\section{METODE PELAKSANAAN}

Metode pelaksanaan pelatihan terdiri atas:

A. Observasi

Observasi ini melibatkan kelompok peternak "Kelinci" dan masyarakat di lingkungan Desa Tanjungsari. Metode yang digunakan dalam observasi ini adalah wawancara dan pengamatan, serta pengumpulan data fisik. Selain itu menggali informasi mengenai upaya warga setempat dan pemerintah dalam mencari pupuk organik alternatif melalui pemanfaatan urin kelinci.

B. Sosialisasi

Proses pelaksanaan terdiri atas sosialisasi dan pelatihan. Sosialisasi yang dilakukan dalam program pengabdian masyarakat ini bertujuan untuk memberi pengetahuan kepada masyarakat tentang pengolahan urin kelinci menjadi pupuk organik cair.

Sosialisasi dilaksanakan pada hari/tanggal : Kamis 03 Agustus 2021, pukul 19.00-21.00 bertempat di rumah bapak Ngadikun (Ketua Kelompok Peternak "Kelinci”). Kegiatan ini diikuti oleh 22 peserta. Materi yang disampaikan antara lain: (1) pengolahan limbah yang berasal dari urin kelinci menjadi pupuk organik; (2) teknik fermentasi; (3) menumbuhkan usaha baru mandiri untuk meningkatkan kesejahteraan keluarga; (4) manajemen pengolahan dan pemasaran produk. Sosialisasi juga dilaksanakan untuk kelompok istri peternak kelinci. Hal ini karena sebagian besar istri peternak kelinci tidak bekerja hanya sebagai ibu rumah tangga. Program sosialisasi pemanfaatan limbah yang berasal dari urin kelinci diharapkan tumbuh kesadaran untuk memanfaatkan limbah urin kelinci menjadi sesuatu yang bernilai ekonomi tinggi. Antusias para istri peternak kelinci ini sangat besar. Mereka berharap pemanfaatan limbah yang berasal dari urin kelinci menjadi pupuk organik bisa membuka lapangan pekerjaan untuk ibu rumah tangga di desa tersebut.

Metode yang digunakan untuk kegiatan sosialisasi terdiri atas:

1. Ceramah, yaitu dengan menyampaikan informasi dan memberi pengarahan tentang manfaat pupuk organik cair serta potensi pengembangan pupuk tersebut secara ekonomis.

2. Diskusi/Tanya jawab: masyarakat diberi kesempatan untuk bertanya tentang hal yang belum dipahami, serta kendala yang mungkin timbul dalam pelaksanaan.

\section{Pelatihan}

Pelatihan pembuatan pupuk organik cair yang berasal dari urin keinci dimaksudkan untuk dapat memperbaiki dan mengembangkan sikap, tingkah laku, keterampilan dan pengetahuan dari peserta sesuai dengan yang diinginkan instruktur. Metode yang digunakan dalam tahap pelatihan ini terdiri atas:

1. Ceramah, dengan narasumber Bapak Ramadhan dari kelompok peternakan kelinci “ maju Makmur" materi yang disampaikan adalah pengalaman yang diperoleh kelompok tersebut setelah melakukan pengolahan limbah yang berasal dari urin kelinci menjadi pupuk organik cair.

2. Demonstrasi dan praktek langsung pembuatan pupuk organik cair dari limbah urin kelinci yaitu dengan menunjukkan cara pembuatan pupuk organik cair untuk kebutuhan sendiri atau lahan pekarangan sebagai pupuk organik yang ramah lingkungan.

Volume 6 Nomor 2 September 2021, DAYA - MAS $\mid 74$ 
Website : http://dayamas.unmermadiun.ac.id/index.php/dayamas

3. Diskusi atau tanya jawab: masyarakat diberi kesempatan tentang hal yang belum dipahami, serta kendala yang mungkin timbul dalam pelaksanaan. Hal ini dilakukan sebagai upaya menggali informasi dan pengetahuan pembuatan pupuk organik cair.

Kegiatan ini dilaksanakan pada hari Selasa 06 Desember 2016 pukul 09.00-10.00, bertempat di rumah bapak Ngadikun (Ketua Kelompok Peternak "Kelinci"). Kegiatan ini diikuti oleh 18 peserta. Setiap peserta diberi kesempatan untuk praktek langsung pembuatan pupuk organik dari urin kelinci. Langkah-langkah dilakukan sebagai berikut:

1. Pencacahan dan perendaman dengan air serta pengendapan hasil rendaman selama 12 jam dilakukan pada daun lamtoro dan batang pisang.

2. Urin kelinci ditampung dan dikumpulkan ke dalam untuk ditambahkan ekstrak batang pisang dan daun lamtoro. Setelah endapan batang pisang dan daun lamtoro didapat, masukkan endapan kedalam ember lalu dilakukan pengadukan dengan ditambahkan EM4 sebagai starter dan tambahkan 200 gram gula merah, selanjutnya tutup rapat ember dan usahakan dalam kondisi anaerob.

3. Penutupan dalam kondisi ini dilakukan selama 18 hari dan diaduk dengan frekuensi 3 hari sekali. Pada hari 18 lakukan airasi selama 24 jam. Setelah dilakukan produk dikemas ke dalam botol produksi dan siap digunakan atau dipasarkan.

D. Pendampingan/Monitoring

Kegiatan pendampingan dilakukan dengan pola Participatory rural appraisal yaitu bekerja sama dengan anggota kelompok tani di Desa Tanjungsari untuk memastikan apakah kondisi masyarakat di lapangan sudah sesuai dengan harapan yang telah ditetapkan. Kegiatan ini meliputi:

1. Motivasi

2. Peningkatan kesadaran terhadap lingkungan untuk memafaatkan limbah urin kelinci

3. Menejemen diri dan mobilisasi Sumber Daya Manusia (SDM)

4. Pengembangan jaringan

\section{HASIL DAN PEMBAHASAN}

Sasaran program ini adalah kelompok peternak "Kelinci" Desa Tanjungsari. Berdasarkan data hasil survei di Desa Tanjungsari, Kecamatan Panekan Kabupaten Magetan menunjukkan bahwa penerapan teknologi pembuatan pupuk organik cair berbahan urin kelinci sangat dibutuhkan masyarakat di wilayah tersebut. Potensi limbah yang berasal dari urin kelinci hanya dianggap limbah yang mencemari lingkungan dan belum termanfaatkan secara optimal. Hasil observasi awal juga diperoleh bahwa masyarakat belum memiliki pengetahuan dan ketrampilan yang cukup pada usaha pengolahan limbah urin kelinci menjadi pupuk organik bernilai ekonomi tinggi. Hasil survei tentang potensi peternakan kelinci dapat dilihat pada Tabel 1.

Tabel 1. Hasil survei kondisi masyarakat

\begin{tabular}{ll}
\hline \multicolumn{1}{c}{ Aktivitas survei } & \multicolumn{1}{c}{ Hasil } \\
\hline Jumlah kepala keluarga (KK) & $53 \mathrm{KK}$ \\
Rata-rata jumlah anggota KK & 4 orang \\
Rata-rata jumlah ternak kelinci & 48 ekor \\
Rata-rata jumlah urin kelinci/hari & 3,25 liter \\
Tingkat pendidikan masyarakat & SD \\
Rata-rata kondisi ekonomi masyarakat & Menengah kebawah \\
Tanggapan masyarakat tentang pupuk organik cair & Tertarik \\
dari urin kelinci & \\
\hline Rata-rata pekerjaan masyarakat & Peternak kelinci, buruh tani \\
\hline
\end{tabular}

Sosialisasi ini dilakukan dalam rangka:

1. Memberikan pengetahuan kepada masyarakat tentang potensi pemanfaatan limbah urin kelinci, sehingga bernilai ekonomi tinggi.

2. Memperkenalkan teknologi pembuatan pupuk organik cair yang berasal dari urin kelinci sebagai pengganti pupuk kimia.

3. Memperkenalkan teknologi pengolahan limbah yang berasal dari urin kelinci menjadi pupuk organik cair bernilai ekonomi tinggi. 
Website : http://dayamas.unmermadiun.ac.id/index.php/dayamas

Hasil sosialisasi menunjukkan antusias para istri peternak kelinci ini sangat besar. Mereka berharap pemanfaatan limbah yang berasal dari urin kelinci menjadi pupuk organik bisa membuka lapangan pekerjaan untuk ibu rumah tangga di desa tersebut. Hal ini ditunjukkan dengan pertanyaan yang diajukan. Selain itu karena telah lama urin kelinci menyebabkan pencemaran lingkungan (menimbulkan bau tidak sedap dan rendahnya tingkat kebersihan di lingkungan peternakan kelinci).

Setiap peserta antusias mengikuti pelatihan pembuatan pupuk organik ini (Gambar 1). Setiap peserta diberi kesempatan untuk praktik langsung pembuatan pupuk oranik cair. Peserta dibagi menjadi 5 kelompok kecil yang terdiri atas 3 anggota. Masing-masing kelompok diberi alat dan bahan untuk pembuatan pupuk organik dari urin kelinci. Setiap kelompok wajib mempraktekkan cara pembuatan pupuk organik dengan didampingi instruktur.

Sebagian besar masyarakat menanggapi positif dan tertarik tentang pengolahan limbah urin kelinci menjadi pupuk organik cair sebagai alternatif penggunaan pupuk kimia. Peternak kelinci di Desa Tanjungsari juga bekerja sebagai buruh tani. Para kelompok tani yang tergabung dalam kelompok peternak "Kelinci”, setiap anggota mempunyai kandang-masing-masing. Anggota kelompok tani ini berjumlah 23 orang, masing-masing anggota rata-rata memiliki kelinci sebanyak 48 ekor. Rata-rata anggota dari kelompok tersebut dapat menghasilkan 3,25 liter/hari. Ini merupakan aset yang berharga bagi desa ini, apabila bisa termanfaatkan dan dikelola dengan baik dan benar.

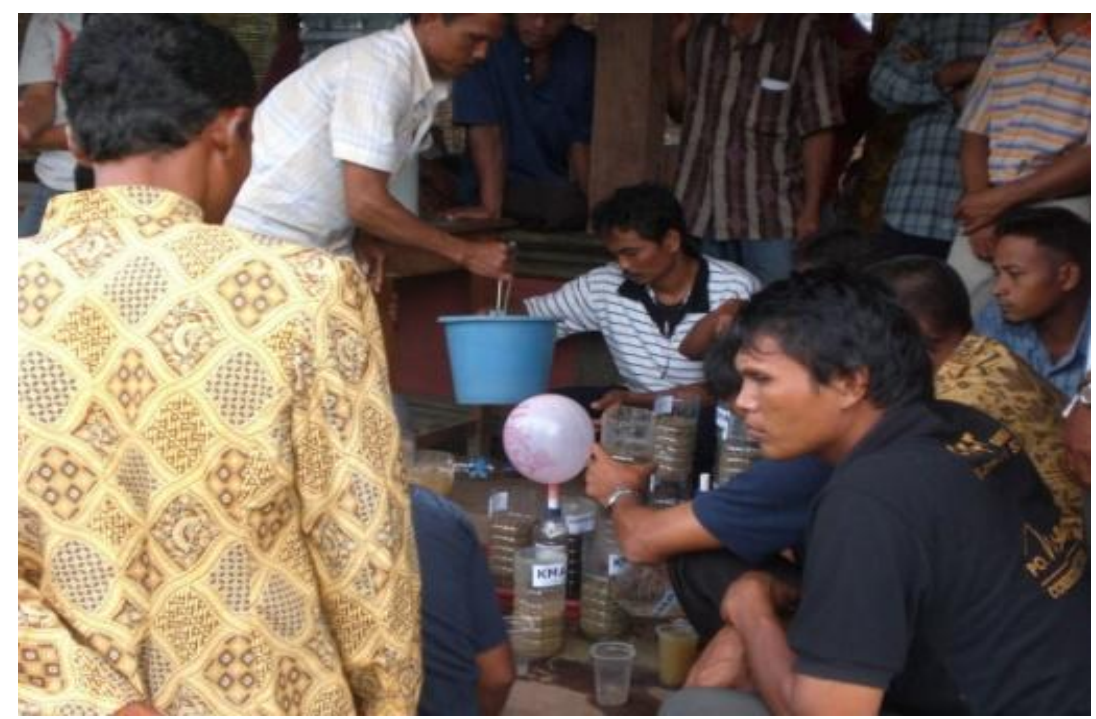

Gambar 1. Pelatihan pembuatan pupuk organik oleh Kelompok Peternak "Kelinci” di Desa Tanjungsari

Setiap peserta diberi kesempatan untuk praktek langsung pembuatan pupuk organik cair. Peserta dibagi menjadi 5 kelompok kecil yang terdiri atas 3 anggota. Masing-masing kelompok diberi alat dan bahan untuk pembuatan pupuk organik dari urin kelinci. Setiap kelompok wajib mempraktekkan cara pembuatan pupuk organik dengan didampingi instruktur.

Sebagian besar masyarakat pada proses pendampingan menanggapi positif dan tertarik tentang pengolahan limbah urin kelinci menjadi pupuk organik cair sebagai alternatif penggunaan pupuk kimia. Peternak kelinci di Desa Tanjungsari juga bekerja sebagai buruh tani. Para kelompok tani yang tergabung dalam kelompok peternak "Kelinci", setiap anggota mempunyai kandang kelinci masing-masing. Anggota kelompok tani ini berjumlah 23 orang, masing-masing anggota rata-rata memiliki kelinci sebanyak 48 ekor. Rata-rata anggota dari kelompok tersebut dapat menghasilkan 3,25 liter/hari. Ini merupakan aset yang berharga bagi desa ini, apabila bisa termanfaatkan dan dikelola dengan baik dan benar.

Upaya kegiatan pendampingan dilakukan melalui kunjungan dan musyawarah antara pelaksana, masyarakat, sehingga limbah ternak dari urin kelinci dapat dimanfaatkan untuk pupuk dan meningkatkan pendapatan masyarakat di Desa Tanjugsari Kecamatan Panekan (Gambar 1). 


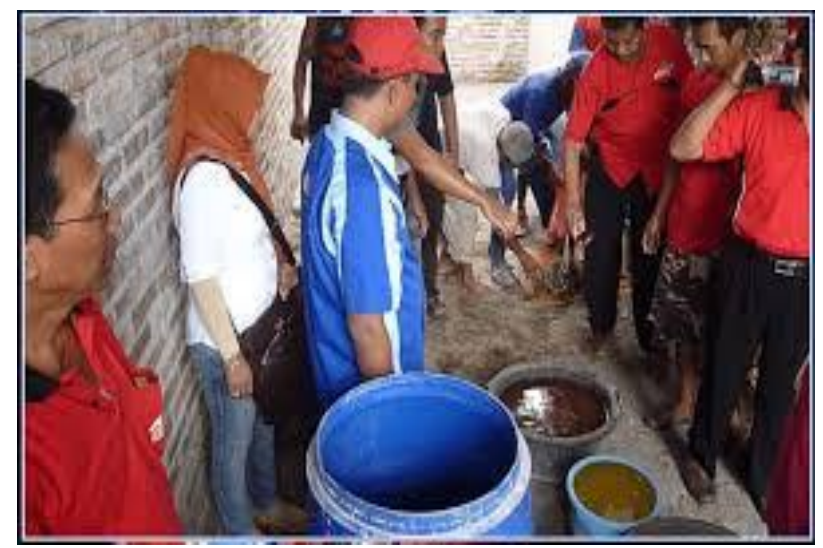

Gambar 2. Program pendampingan pembuatan pupuk organik dari urin kelinci

Perubahan yang dapat dilihat dari masyarakat di Desa Tanjungsari setelah mengikuti pendampingan pemanfaatan urin kelinci untuk pupuk organik cair antara lain:

1. Meningkatkan kesadaran masyarakat khususnya Kelompok Peternak "Kelinci" tentang: a) limbah ternak berupa urin kelinci dapat diolah menjadi bahan yang bernilai ekonomi agar tidak mencemari lingkungan;

b) urin kelinci dapat diolah menjadi pupuk organik cair berguna untuk tanaman.

2. Tumbuhnya minat masyarakat untuk produksi pupuk organik cair.

3. Meningkatkan keterampilan masyarakat untuk membuat pupuk organik yang berkualitas dari urin kelinci.

4. Terbentuknya kelompok usaha pengolahan urin kelinci menjadi pupuk organik bernilai ekonomi, sehingga menambah penghasilan masyarakat setempat.

5. Lingkungan peternakan kelinci menjadi lebih bersih, karena kotoran kelinci yang awalnya mencemari lingkungan menyebabkan bau, sekarang termanfaatkan untuk usaha baru yaitu pembuatan pupuk organik cair.

Kendala yang dihadapi pada saat pendampingan antara lain:

1. Keterbatasan waktu pelaksanaan pelatihan, sehingga materi tentang pemasaran produk pupuk organik yang berasal dari urin kelinci tersebut masih kurang.

2. Keterbatasan biaya dalam pelatihan dan pendampingan.

Berdasarkan evaluasi pelaksanaan dan hasil kegiatan dapat diidentifikasi faktor pendukung dalam melaksanakan program pengabdian masyarakat ini adalah:

1. Kualifikasi pelaksana adalah dosen perlindungan tanaman.

2. Antusiasme peserta pelatihan cukup tinggi karena sebagian besar dari peserta tidak memiliki pengetahuan yang cukup mengenai pemanfaatan urin kelinci dan pupuk organik cair.

3. Kondisi alam lingkungan atau potensi lokal yang dimiliki Desa Tanjungsari, semangat dari tokoh masyarakat dan dukungan moral dari Kepala Desa.

4. Keterbukaan berbagi ilmu dan bantuan dari kelompok tani "Maju Makmur" tentang seluk beluk pengolahan urin kelinci.

A. Kesimpulan

\section{KESIMPULAN DAN REKOMENDASI}

Berdasarkan hasil analisa program pengabdian masyarakat telah dilakukan teknologi tepat guna pemanfaatan urin kelinci menjadi pupuk organik di Desa Tanjungsari Kecamatan Panekan Kabupaten Magetan dapat disimpulkan sebagai berikut:

a. Ditinjau dari aspek capaian berdasarkan tujuan, substansi dan usaha program pengabdian masyarakat ini dipandang sangat efektif untuk membangun kemandirian masyarakat yang berbasis potensi lokal yakni limbah yang berasal dari urin kelinci.

b. Ditinjau dari aspek hasil, manfaat dan dampak yang dihasilkan dari program pengabdian masyarakat ini sangat banyak yaitu: meningkatkan kesadaran masyarakat untuk memanfaatkan limbah yang berasal dari urin kelinci untuk pupuk organik cair, meningkatkan pengetahuan dan keterampilan masyarakat bidang pengolahan limbah yang berasal dari urin kelinci menjadi pupuk organik cair, tumbuhnya kelompok usaha pengolahan pupuk organik cair di Desa Tanjungsari, Kecamatan Panekan Kabupaten Magetan. 
Website : http://dayamas.unmermadiun.ac.id/index.php/dayamas

\section{B. Rekomendasi}

Peternak kelinci di Desa Tanjungsari telah berhasil membuat pupuk organik cair dari urin kelinci namun belum dipasarkan. Agar pengelolaan dalam pembuatan dan pemasaran pupuk organik cair dari urin kelinci tersebut berlangsung lancar, maka perlu dibentuk kelompok usaha pemasaran pupuk organik yang dihasilkan.

\section{UCAPAN TERIMAKASIH}

Penulis mengucapkan terimakasih kepada Kepala Desa Tanjungsari dan Camat Panekan Kabupaten Magetan yang telah menfasilitasi Pengabdian kepada Masyarakat, serta masyarakat yang telah sangat antusias menerima program Pengabdian kepada Masyarakat dari penulis.

\section{DAFTAR PUSTAKA}

Hardjowigeno, S. 2003. Ilmu tanah. Akademika Presindo, Jakarta.

Kusnendar,.2013. Pupuk organik dari urin kelinci, Diakses tanggal 28 November 2016.

Kristanto P. 2002. Energi industri, Yogyakarta:ANDI.

Mahida U.N. 1984. Pencemaran air dan pemanfaatan limbah industri, Jakarta: Rajawali.

Mutryarny E., Endriani dan Lestari S.U. 2014. Pemanfaatan urin kelinci untuk menghasilkan pertumbuhan dan produksi tanaman sawi (Brassica yuncea L.) varietas Tosaka. Jurnal Ilmiah Pertanian 11(2): 23-34.

Naswir. 2003. Pemanfaatan urin sapi yang difermentasi sebagai nutrisi tanaman. http://tumoutou.net/702_07134/naswir.htm. 28 Desember 2016. 